Katarzyna Dudziak* (iD https://orcid.org/0000-0002-4884-5403

\title{
Zjawisko wykluczenia zawodowego osób g/Głuchych w procesie rekrutacji w Polsce
}

https://doi.org/10.25312/2391-5129.32/2021_06kd

\begin{abstract}
Wykluczenie zawodowe dotyka g/Głuchych bez względu na wiek, status majątkowy, poziom wykształcenia czy miejsce zamieszkania. Skala zjawiska wykluczenia zawodowego osób z uszkodzeniem słuchu w Polsce pomimo postępu technologicznego oraz rozwoju w obszarze zarządzania kapitałem ludzkim odbiera możliwość pełnego ich uczestnictwa w życiu społecznym. Gdzie należy szukać przyczyn tego rodzaju marginalizacji? Czy aby respektować prawo człowieka do aktywności zawodowej, potrzeba konwencji? Jeśli tak, to czy odpowiedzialność za realizację przepisów i rekomendacji leży po stronie państwa czy organizacji? Wyobrażenia na temat g/Głuchych oraz dysfunkcji słuchu przez lata zbudowały silne uprzedzenia w świecie słyszących. I chociaż dziś sami zainteresowani wychodzą, żeby manifestować swoją potrzebę aktywności zawodowej, to mimo to $w$ dalszym ciągu pozostają na marginesie procesu rekrutacji.
\end{abstract}

Słowa kluczowe: Głusi, wykluczenie zawodowe, proces rekrutacji, stereotypy, zarządzanie różnorodnością

\section{Wstęp}

W systemie społeczno-gospodarczym aktywność zawodowa człowieka ma znaczenie ekonomiczne, socjalizacyjne, jak również emocjonalne i rehabilitacyjne. W tych wymiarach jest środkiem służącym zaspokajaniu potrzeb bytowych, umożliwiającym rozwój i nabywanie nowych umiejętności, wspieraniu autonomii i niezależności jednostki poprzez budowanie własnej wartości, aż do realizowania przez nią określonych zadań służących uzyskaniu dóbr istotnych dla całego społeczeństwa. Możność stracji.

Katarzyna Dudziak - mgr, Uniwersytet Jagielloński w Krakowie, Wydział Prawa i Admini- 
realizowania posiadanych kompetencji zawodowych na rynku pracy kształtowana jest przez wiele czynników. Należą do nich: edukacja, prawo pracy, sytuacja gospodarcza, cechy demograficzne czy jednostkowe. Każdy człowiek na pewnym etapie swojego życia może stać się osobą wykluczoną. W przypadku niepełnosprawnych $\mathrm{z}$ uszkodzeniem słuchu bariera $\mathrm{w}$ dostępie do pracy formowana jest poprzez stereotypowe wyobrażenie pracodawców na temat osób g/Głuchych ${ }^{1}$. Występująca wśród g/Głuchych bierność zawodowa w dużej mierze poprzedzona jest długotrwałym dyskryminowaniem już na etapie procesu rekrutacji. Na ten stan bezpośrednio wpływa nastawienie pracowników zajmujących się rekrutacją w organizacjach, jak również ich ograniczona wiedza oraz brak doświadczenia w zakresie współpracy z kandydatami z niepełnosprawnością słuchową. Wykluczenie zawodowe osób z dysfunkcją słuchu jest faktem. Pomimo wdrażanej w przedsiębiorstwach koncepcji zarządzania różnorodnością, ratyfikowanej przez Polskę konwencji o prawach osób niepełnosprawnych oraz obowiązującej ustawy o języku migowym i innych środkach komunikowania się sytuacja zawodowa osób z uszkodzeniem słuchu jest głęboko niekorzystna.

Celem niniejszego artykułu jest ukazanie zjawiska wykluczenia zawodowego g/Głuchych w procesie rekrutacji z uwzględnieniem jego złożoności.

W pracy przyjęto następującą hipotezę badawczą: „brak świadomej polityki personalnej w organizacji skutkuje wykluczeniem zawodowym osób z uszkodzonym słuchem z procesu rekrutacji”.

W pracy przeprowadzono przegląd dostępnej literatury z zakresu tematyki dotyczącej zagadnienia związanego z wykluczeniem osób g/Głuchych w procesie rekrutacji oraz dokonano analizy badań różnych autorów oraz badań własnych. Zagadnienia opracowano w oparciu o literaturę przedmiotu oraz źródła internetowe.

\section{Wprowadzenie do problematyki wykluczenia zawodowego}

Człowiek w rozwoju własnym i społecznym poddany jest dwóm procesom: powstawania potrzeb oraz ich zaspokajania. To one determinują szereg zachowań ludzkich. Podejmowana przez człowieka specyficzna forma aktywności jest „wynikiem długotrwałego procesu rozwoju umysłowego, społecznego i kulturowego" (Skorny, 1989: 6). Pojęcie działalności ludzkiej w praktyce oznacza zamierzone i zorganizowane ukierunkowanie na realizację określonego celu. W aspekcie zawodowym są to postawy świadomego poszerzania kompetencji, aktywnego poszukiwania pracy,

${ }^{1}$ Zapis $g /$ Gtuchy, g/Glucha jest to zapis hybrydowy, który wskazuje na świadomość różnicy w występowaniu osób głuchych (kontekst medyczny) i Głuchych (kontekst kulturowy). Zapis ten nie rozstrzyga znaczenia. Zapis małą literą (głuchy, głucha) odnosi się do osoby z uszkodzonym słuchem (kontekst medyczny). Zapis wielką literą (Gtuchy, Glucha) odnosi się do osób z uszkodzeniem słuchu, które identyfikują się ze światem Głuchych (kontekst kulturowy) (zob. Szkoła tolerancji, Centrum Edukacji Obywatelskiej). 
aż do wykonywania powierzonych zadań. Brak możliwości uczestniczenia w procesie produkcji społecznej staje się barierą również w wielu innych obszarach życia, nasilając zjawisko marginalizacji. W odniesieniu do osób głuchych marginalizacja nie jest społecznie jednorodna (Lipczyński, 2015: 58). Z jednej strony środowisko osób niepełnosprawnych słuchowo zabezpieczone zostało materialnie przez ustawodawcę, a kwestię pokonywania trudności komunikacyjnych między innymi z instytucjami administracji publicznej uregulowano Ustawą z dnia 19 sierpnia $2011 \mathrm{r}$. o języku migowym i innych środkach komunikowania się. Z drugiej jednak strony, jak wskazuje Z. Teper-Solarz (2013: 119-120), szansa na znalezienie zatrudnienia przez osoby g/Głuche i słabosłyszące jest najniższa wśród osób z orzeczeniem innej kategorii niepełnosprawności. Powodem powyższego twierdzenia jest szereg ograniczeń, z jakimi osoby z uszkodzonym słuchem spotykają się na etapie przygotowania do pracy oraz jej uzyskania. Do głównych przeszkód zaliczono:

- kwestie legislacyjne,

- kompetencje,

- bariery społeczne,

- czynniki psychologiczne (Dunaj, 2014: 89-102).

Brak możliwości uczestnictwa g/Głuchych w ważnych aspektach życia społeczno-ekonomicznego to efekt procesu, który, jak uważa K. Faliszek (2008: 71), ukształtowany zostaje przez przeżycia, jakich doświadczają jednostki bądź grupy w strukturze społecznej. Ten proces wykluczenia społecznego ma według P. Kubickiego swój początek w istotnym zdarzeniu pogarszającym sytuację życiową jednostki (Kubicki, 2011). Wraz z upływem czasu, jak podkreśla badacz, ulega on intensyfikacji, przyczyniając się do dalszej degradacji, w tym ujęciu - zawodowego obszaru życia. Prowadzi to do pełnego wykluczenia jednostki lub grupy, całkowicie uzależniając zmianę sytuacji życiowej od pomocy z zewnątrz (Niewiadomska, 2018 : 156). Prezentująca się w taki sposób sytuacja życiowa, w której nastąpiła długotrwała deprywacja potrzeby zaprezentowania kandydatury w procesie rekrutacji, czego efektem jest ograniczenie uczestnictwa w procesie pracy, jak wskazują badacze jest stanem wykluczenia zawodowego. Wykluczenie zawodowe uznawane jest w literaturze przedmiotu za jeden z wymiarów szeroko pojętego wykluczenia społecznego. Związane jest ono ściśle $\mathrm{z}$ brakiem sposobności do efektywnego funkcjonowania na rynku pracy lub/i postrzegania jednostki w procesie rekrutacji jako tej niezdolnej do bycia uczestnikiem systemu społeczno-gospodarczego.

W zarysowane powyżej rozważania dotyczące wykluczenia zawodowego należy włączyć zewnętrzne czynniki, które sprzyjają wykluczeniu z procesu rekrutacji osób głuchych. Wiążą się one z terminem dyskryminacji, często używanym równolegle z pojęciem wykluczenia. Nierówne traktowanie, wybiórcza ocena, nieuzasadnione i niesprawiedliwe postawy społeczne mają swą przyczynę w przynależności jednostki do danej grupy społecznej lub konkretnej kategorii (Tabin, 2005: 494). Stereotypy na temat możliwości fizycznych i umysłowych osób z uszkodzeniem słuchu, niera- 
cjonalne poglądy pracowników działu kadr znajdują wyraz w odrzuceniu na wczesnym etapie rekrutacji kandydatury osoby z uszkodzonym słuchem bez sprawdzenia jej kompetencji, stając się jednocześnie odmową realizowania praw społecznych g/Głuchych obywateli.

\section{Sytuacja g/Głuchych na rynku pracy w Polsce}

W krajowej polityce zatrudniania osób z niepełnosprawnością, także tą sensoryczną, zawarto dwie kategorie. Pierwsza z nich podlega wymogom prawnym i organizacyjnym, mając na celu wspieranie zatrudniania g/Głuchych na otwartym rynku pracy. Zatrudnienie w tym przypadku możliwe jest w dwóch formach. Pierwsza ma miejsce wtedy, gdy organizacja poszukuje pracownika niepełnosprawnego na stanowisko pracy stricte przystosowane do kandydata $\mathrm{z}$ dysfunkcją słuchu. Z kolei druga forma kieruje się zasadą konkurencyjności. Wówczas pracodawca zaprasza do udziału w rekrutacji wszystkich zainteresowanych, nie wyłączając kandydatów z orzeczeniem o niepełnosprawności. Druga kategoria to chroniony rynek pracy (ang. Sheltered Enterprises), w którym tworzone są specjalne warunki pracy dla osób niepełnosprawnych (Golinowska, 2004: 237).

W ramach projektu Deaf Work (Głusi w pracy) przeprowadzono badanie w organizacjach zatrudniających pracowników z niepełnosprawnością słuchową, które dotyczyło zalet głuchych i słabosłyszących. Wyróżniono takie zalety g/Głuchego pracownika, jak:

- sumienność,

- dokładność i skrupulatność,

- zaangażowanie,

- pracowitość,

- uczciwość,

- przywiązanie do miejsca pracy (zdaniem pracodawców głusi rzadziej zmieniają pracę niż słyszący),

- dbanie o porządek,

- większa wydajność/efektywność,

- umiejętność skupienia się na pracy (brak rozproszenia rozmowami ze współpracownikami),

- predyspozycje do pracy wymagającej cierpliwości i precyzji,

- wyczucie estetyki,

- zdolności manualne,

- zmysł obserwacji,

- dobra organizacja pracy (,,Gtuchy pracownik”. Poradnik dla pracodawców).

Jak pokazała praktyka, g/Głusi to pracownicy zaangażowani. Ich potencjał i zdolności odkrywane są w każdym niemal zawodzie, przede wszystkim wyuczonym. Coraz większa część tego środowiska, w szczególności osoby w wieku produk- 
cyjnym, zdobywa wyższe wykształcenie. Osoby g/Głuche pomimo niezależnych od nich trudności w systemie edukacji, stają się przedsiębiorcami, a nawet specjalistami, nierzadko ponadprzeciętnymi. Ponadto zatrudnianie osób z niepełnosprawnością słuchową nie powoduje istotnych komplikacji, przeciwnie - może przynieść organizacji wiele korzyści w zakresie zwrotu kosztów utworzenia lub dostosowania stanowiska pracy czy refundacji wynagrodzeń. Dodatkowo w aspekcie pozafinansowym organizacja kierująca się społeczną odpowiedzialnością biznesu (ang. Corporate Social Responsibility - CRS) zyskuje wizerunek przedsiębiorstwa dbającego o interesy społeczne, a wdrożona w miejscu pracy koncepcja zarządzania różnorodnością (ang. Diversity Management) jest wyrazem poszanowania człowieka, który bez względu na swoją niepełnosprawność ma prawo do równego traktowania przy zatrudnieniu. Tymczasem wyniki zrealizowanych przez Główny Urząd Statystyczny badań pt. Osoby niepetnosprawne na rynku pracy w 2011 r. prezentują pesymistyczny obraz silnej tendencji nieuwzględniania w obszarze zawodowym osób z dysfunkcją słuchu (Osoby niepetnosprawne na rynku pracy w 2011 r., 2012).

Tabela 1. Status osób głuchych na rynku pracy

\begin{tabular}{|c|c|c|c|c|}
\hline \multirow{2}{*}{ Rodzaj trudności } & \multicolumn{4}{|c|}{ Status na rynku pracy } \\
\cline { 2 - 5 } & ogółem & pracujący & bezrobotni & $\begin{array}{c}\text { bierni } \\
\text { zawodowo }\end{array}$ \\
\cline { 2 - 5 } & & \multicolumn{4}{|c|}{ Liczba osób w tys. } \\
\hline Słyszenie, nawet z aparatem słuchowym & 115 & 33 & 7 & 75 \\
\hline
\end{tabular}

Źródło: Osoby niepełnosprawne na rynku pracy w 2011 r., 2012.

Wynik 71,3\% niepracujących i biernych zawodowo wskazuje bezsprzecznie na zjawisko marginalizacji g/Głuchych z przyczyn zewnętrznych. Dodatkowo analiza prowadzonych przez wiele lat badań świadczy o tym, jak bardzo zakorzeniona jest w świadomości pracodawców niechęć do zatrudniania na otwartym rynku pracy osób niepełnosprawnych (Kryńska, 2013: 50). Aktywność zawodowa niesłyszących pracowników na polskim rynku pracy najczęściej koncentruje się w szarej strefie (Teper-Solarz, 2016: 43). Oferty prostych prac niewymagających posługiwania się językiem narodowym czy pozbawione wymogu posiadania wysokich kwalifikacji to propozycje najczęściej przedstawiane g/Głuchym kandydatom.

Tabela 2. Lista zawodów, w których pracują osoby z uszkodzeniem słuchu w wieku 15-64 lat

\begin{tabular}{|l|c|}
\hline \multicolumn{1}{|c|}{ Zawód } & Liczba osób w tys. \\
\hline pracownicy przy prostych pracach & 6 \\
\hline rolnicy, ogrodnicy, leśnicy i rybacy & 5 \\
\hline robotnicy przemysłowi i rzemieślnicy & 9 \\
\hline
\end{tabular}


Tabela 2 cd.

\begin{tabular}{|l|c|}
\hline \multicolumn{1}{|c|}{ Zawód } & Liczba osób w tys. \\
\hline przedstawiciele władz publicznych, wyżsi urzędnicy & - \\
\hline specjaliści & - \\
\hline technicy i inny średni personel & - \\
\hline operatorzy i monterzy maszyn i urządzeń & - \\
\hline
\end{tabular}

Źródło: opracowanie na podstawie wyników badań Świdziński, 2014.

Pamiętając o złożoności powyższej sytuacji, trzeba mieć świadomość, że ograniczanie g/Głuchych w wykonywaniu funkcji zawodowych i społecznych, a przede wszystkim odbieranie im możliwości zaprezentowania siebie w procesie rekrutacji są jednymi z głównych czynników wykluczenia zawodowego tej mniejszościowej grupy społecznej.

Wobec powyższego twierdzenie E. Rudnickiej (2011: 65-77) dotyczące negatywnego kojarzenia terminu głuchy wśród społeczeństwa słyszącego, a tym samym krzywdzącego postrzegania osoby niesłyszącej jako niepełnowartościowego kandydata do pracy wydaje się znajdować odzwierciedlenie. W porównaniu do innych krajów Unii Europejskiej w Polsce wskaźniki aktywności zawodowej osób niepełnosprawnych z dysfunkcją słuchu są bardzo niskie, a przyczyn zewnętrznych tego stanu jest wiele. Tym bardziej zastanawia fakt aktywności zawodowej g/Głuchych w innych państwach. Podejmują oni pracę na różnych stanowiskach, które w Polsce dla osób z uszkodzeniem słuchu są niedostępne z powodu stereotypowego podejścia społeczeństwa, ograniczeń medycyny pracy pomijającej społeczny model głuchoty i nieprzygotowanych do współpracy z g/Głuchymi organizacji.

\section{Przyczyny wykluczenia zawodowego g/Głuchych}

Ograniczenie dostępności zawodów dla g/Głuchych kandydatów opiera się wyłącznie na wskazaniu rodzajów pracy, których nie należy proponować osobom z wadą słuchu. Decyzja o możliwości wykonywania zawodu przez g/Głuchego pracownika podejmowana jest indywidualnie przez lekarza medycyny pracy (Świdziński, 2014: 94). Na tym etapie wiele zależy od organizacji poszukującej pracownika. Profesjonalny opis stanowiska uwzględniający czynniki ryzyka oraz praktyczne wskazówki, które będą stanowić o możliwości pokonywania trudności, zwiększają szansę na powodzenie w procesie zatrudnienia. Tymczasem g/Głusi zgodnie z przyjętym modelem medycznym postrzegani są w społeczeństwie jako niepełnosprawni. Co za tym idzie uwaga rekruterów w pierwszej kolejności skupiona jest na deficycie, jakim jest wada słuchu. Brak rzetelnej wiedzy dotyczącej komunikacji wizualno-przestrzennej g/Głuchych (polski język migowy) wśród specjalistów, pracodawców, a przede wszystkim pracowników działów kadr oraz działów HR zajmujących się 
zarządzaniem zasobami ludzkimi (ang. Human Resources) znacząco utrudnia kandydatom z uszkodzeniem słuchu uczestniczenie w procesie rekrutacji.

Ograniczona wiedza i brak doświadczenia w zakresie współpracy z osobami z niepełnosprawnością

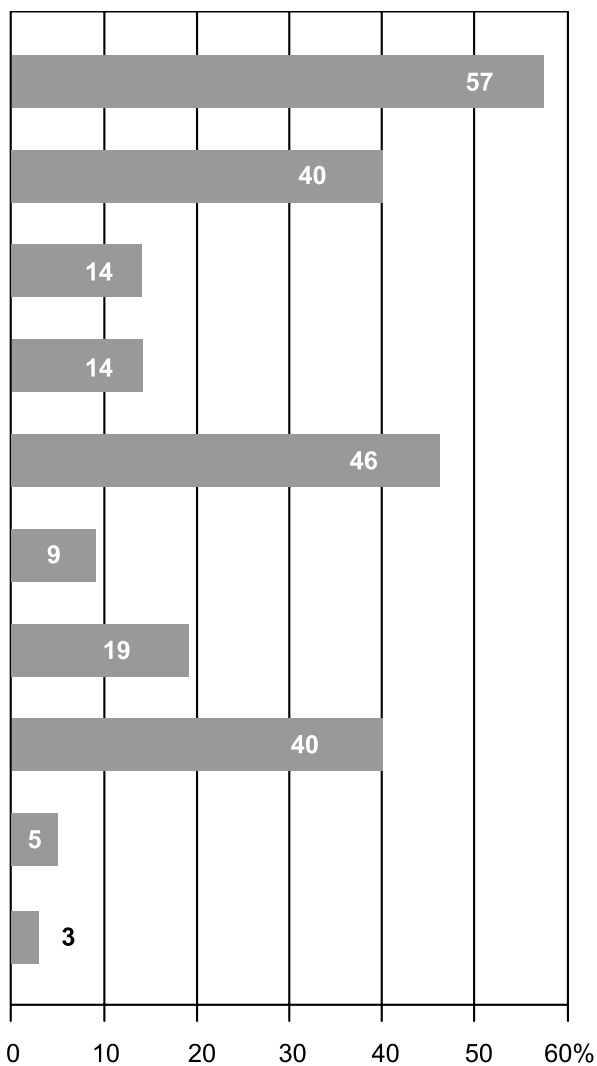

Rysunek 1. Czynniki utrudniające zatrudnianie osób niepełnosprawnych Źródło: Piotrowska, 2015: 21.

Polskie ustawodawstwo usankcjonowało 1 kwietnia 2012 roku polski język migowy (PJM) jako język, pomimo to organizacje poszukujące pracowników pozwalają sobie w procesie rekrutacji na audyzm. Jest to krzywdzące przekonanie, że osoby g/Głuche są mniej zdolne i nie będą w stanie posiąść odpowiednich kwalifikacji, by tak jak osoby słyszące wykonywać określone zawody w sposób efektywny. Taka opinia przyczynia się do odrzucenia kandydatur g/Głuchych na wczesnym etapie rekrutacji (Biuletyn Informacji Publicznej RPO, Rzecznik Praw Obywatelskich).

Czynniki wykluczenia zawodowego niepełnosprawnych podkreślane są niejednokrotnie przez badaczy w pracach dotyczących wykluczenia społecznego. Do najczęściej wskazywanych przyczyn utrudniających zatrudnienie kandydatów z orzeczeniem o niepełnosprawności należą:

- brak wiedzy o osobach niepełnosprawnych ze strony pracodawców,

- nieprawidłowe postawy społeczne, 
- utożsamianie niepełnosprawności z brakiem kwalifikacji oraz brakiem motywacji do pracy, nawykiem uzależnienia od innych osób,

- bariery komunikacyjne i architektoniczne (Kukla, 2004: 66).

Powyższe uwarunkowania obserwujemy w organizacjach, które nie posiadają właściwej polityki w strukturze zatrudnienia (ang. Human Resources Management). Niepodejmowanie działań kładących nacisk na stosowanie zasady równości w procedurach rekrutacyjnych czy rozbudowywania zaplecza merytorycznego w zakresie współpracy z osobami g/Głuchymi, brak inicjatyw na rzecz środowisk zawodowo wykluczonych czy nieuwzględnianie niepełnosprawności w zarządzaniu zasobami ludzkimi są efektem braku świadomej polityki personalnej. We właściwej polityce personalnej organizacji „prócz zwiększenia różnorodności pracowników, pożądane są także umiejętności efektywnego zarządzania różnorodnością i tworzenia środowiska, które gwarantuje szacunek i równość dla wszystkich” (Klincewicz, 2016). Oznacza to konieczność zmiany profilu pracownika (ang. Person Specyfications). Zarządzanie różnorodnością (ang. Diversity Management) wyszczególnia cechy pożądane każdego zatrudnionego, takie jak:

- otwartość,

- wrażliwość ekologiczna,

- doświadczenie międzykulturowe,

- przekonanie do zasady równych szans (National activity Report Slovakia anti-discrimination and diversity training, 2008: 12).

Otwartość pracowników zajmujących się procesem rekrutacji w organizacji oraz ich przekonanie do zasady równych szans jest niezbędne w tworzeniu świadomej polityki personalnej. Tymczasem kompleksowy proces mający na celu przyciągnięcie kandydatów na określone stanowisko nie uwzględnia Głuchych jako pełnowartościowych przyszłych pracowników, a wręcz ich pomija. Powyższe twierdzenie znajduje odzwierciedlenie w podsumowaniu V seminarium specjalistycznego pt. Niepetnosprawność wzrokowa, wzrokowo-stuchowa i niepetnosprawność stuchowa jako przesłanki dyskryminacji. Fundacja Fundusz Współpracy i Towarzystwo Edukacji Antydyskryminacyjnej wskazała powszechną praktykę pracodawców, jaką jest rezygnacja z przeprowadzenia rozmowy kwalifikacyjnej z kandydatem z dysfunkcją słuchu (Gross-Gołacka, 2018).

Wobec powyższego deficyt uczestnictwa Głuchych w procesie rekrutacji jest wynikiem społecznego przeświadczenia o tym, że niepełnosprawność słuchowa jest odchyleniem od normy fizycznej i psychicznej, skutkującym znacznym ograniczeniem w funkcjonowaniu zawodowym i społecznym. Postrzeganie głuchego kandydata przez pryzmat standaryzacji jakości ludzkich możliwości powoduje niepodejmowanie przez lekarzy medycyny pracy, urzędników oraz pracodawców działań na rzecz zmiany sytuacji zawodowej Głuchych, a przede wszystkim kroków dla stwarzania równych szans i zapobiegania przejawom dyskryminacji. Osoby Głuche spotykają się z brakiem profesjonalnej postawy ze strony rekruterów, a z kolei brak dobrych 
praktyk w budowaniu kultury organizacyjnej w organizacjach poszukujących pracownika uniemożliwia osobom z uszkodzeniem słuchu budowanie pełnej tożsamości zawodowej, w wyniku czego zjawisko wykluczenia zawodowego nasila się.

\section{Wykluczenie zawodowe g/Głuchych $\mathrm{w}$ procesie rekrutacji - wyniki badań własnych}

Przeprowadzone w 2020 roku badania własne na próbie badawczej, która objęła 25 organizacji świadczących wyłącznie usługi rekrutacyjne dla firm, wyraźnie ukazały zjawisko problemu, jakim jest brak otwartości organizacji w uwzględnianiu g/Głuchych kandydatów w procesie rekrutacji. Losowo wybranym organizacjom zajmującym się procesem zatrudnienia w Polsce zadano pytanie o to, ile procesów rekrutacyjnych zostało przeprowadzonych z uwzględnieniem osób g/Głuchych w latach 2014-2019. W odpowiedzi uzyskano następujące dane: 96\% organizacji nie przeprowadziło żadnej rekrutacji uwzględniającej udział kandydatów g/Głuchych, $4 \%$ nie odpowiedziało.

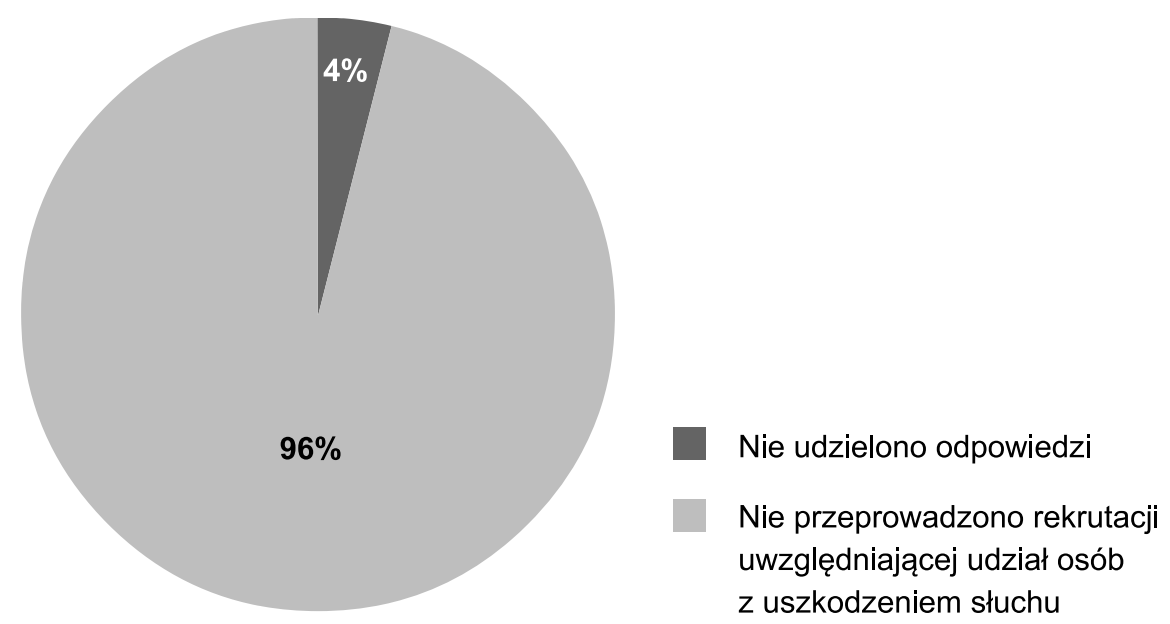

Rysunek 2. Liczba przeprowadzonych procesów rekrutacyjnych w latach 2014-2019 z uwzględnieniem kandydatów g/Głuchych i słabosłyszących

Źródło: badania własne.

Uzyskany wynik (rys. 2), choć nie diagnozuje wystarczająco problemu, prowokuje do poszukiwania przyczyny takiego stanu rzeczy. Wśród stanowisk przedstawicieli reprezentujących organizacje rekrutujące poza nieudzieleniem odpowiedzi (4\%), wymieniono ogólnie brak decyzyjności co do publikacji ogłoszenia otwartego także dla kandydatów niepełnosprawnych (80\%). Kolejnym z powodów według działu kadr jest brak funduszy na wsparcie komunikacji z osobą niesłyszącą lub/i nieposiadanie przez zatrudnianych rekruterów znajomości języka migowego (12\%). Ostatnią 
z grupy udzielonych odpowiedzi było wskazanie konkretnych procesów rekrutacyjnych dla stanowisk kierowniczych i specjalistycznych, które według przedstawiciela agencji HR wymagają dobrze rozwiniętych umiejętności komunikacyjnych (4\%) (Dudziak, 2020: 25).

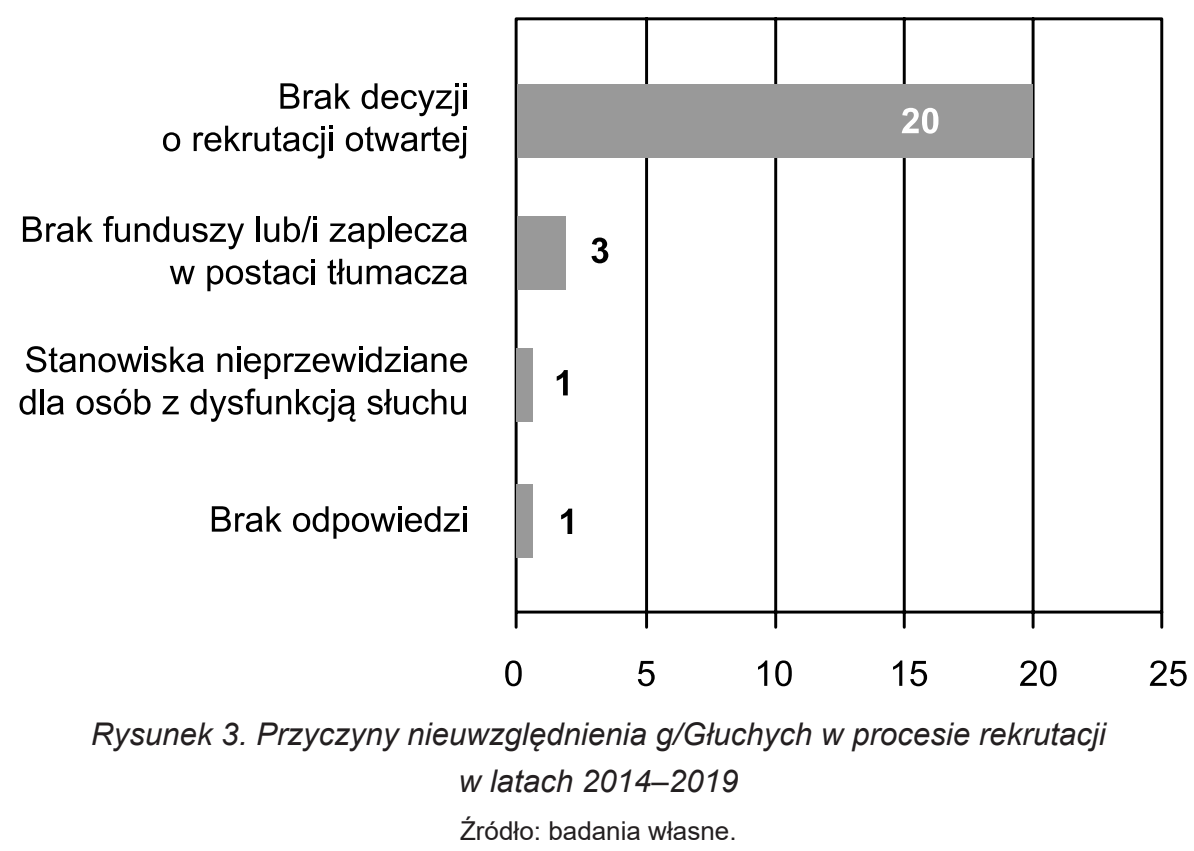

Powyższą dysfunkcję procesu rekrutacji potwierdzają sami zainteresowani, którzy zostali poproszeni o udział w badaniu dotyczącym omawianego zakresu. Osoby g/Głuche (próba badawcza licząca 57 osób) w przeprowadzonych badaniach własnych z wykorzystaniem autorskiego kwestionariusza ankiety wskazały na zdecydowane pomijanie ich kandydatur w procesie rekrutacji (78,9\%), odmiennego zdania było $21,1 \%$ ankietowanych. Ponadto $70,2 \%$ respondentów oceniło agencje rekrutacyjne jako nieprzygotowane do prowadzenia procesu zatrudnienia uwzględniającego kandydatury osób z uszkodzeniem słuchu, a około 29,8\% osób z uszkodzeniem słuchu ma odmienne stanowisko. 


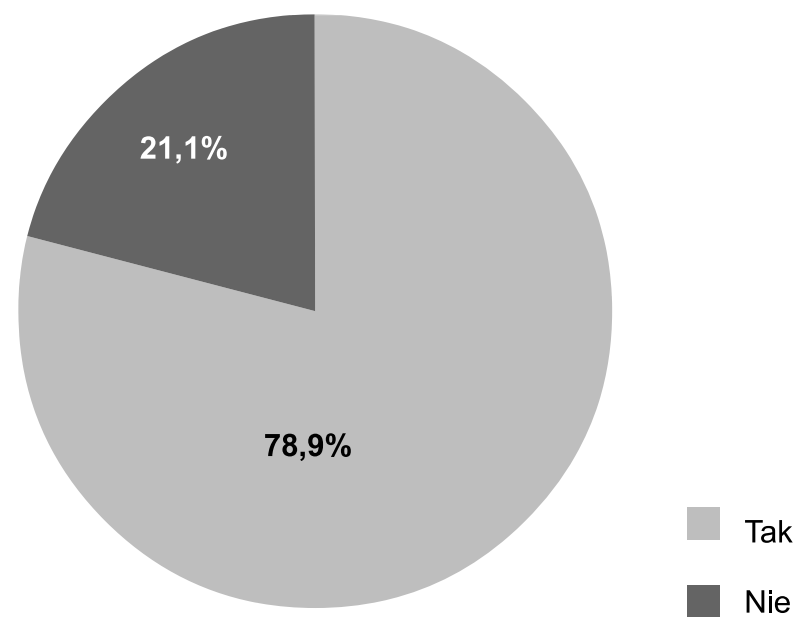

Rysunek 4. Pomijanie kandydatów głuchych i słabosłyszących w procesie rekrutacji w opinii respondentów

Źródło: opracowanie własne.

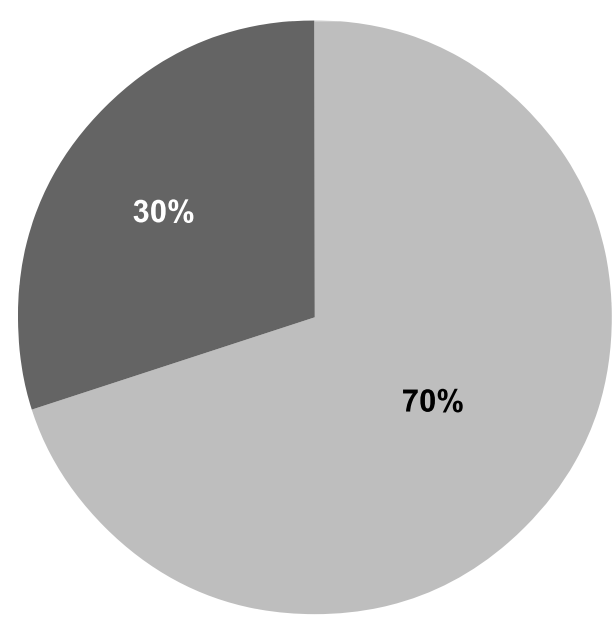

$\mathrm{Nie}$

Tak

Rysunek 5. Ocena przygotowania agencji HR do prowadzenia rekrutacji dla kandydatów z dysfunkcją słuchu

Źródło: badania własne.

Wśród kobiet, które stanowiły 63\% ankietowanych, aż 42\% osób z uszkodzeniem słuchu ukończyło studia wyższe lub jest w trakcie zdobywania tytułu zawodowego. Jak pokazują wyniki badań, podnoszenie kwalifikacji staje się dla omawianej grupy społecznej istotnym elementem wzmacniającym jej aktywność zawodową i zwiększającym atrakcyjność na rynku pracy. Tymczasem aż 78,9\% ogółu biorących udział w badaniu kwestionariuszem uważa, że rynek pracy w Polsce jest zamknięty na nich jako kandydatów starających się o zatrudnienie. Niewiele, bo tylko 
14,1\% g/Głuchych twierdzi, że organizacje otwierają się na kandydatów sensorycznie niepełnosprawnych. Pozostałe 3,5\% ogółu badanych uważa, że rynek pracy jest otwarty, lecz w niewystarczającym stopniu, a kolejne 3,5\% respondentów sądzi, że wszystko zależy od wykonywanego zawodu (Dudziak, 2020: 48).

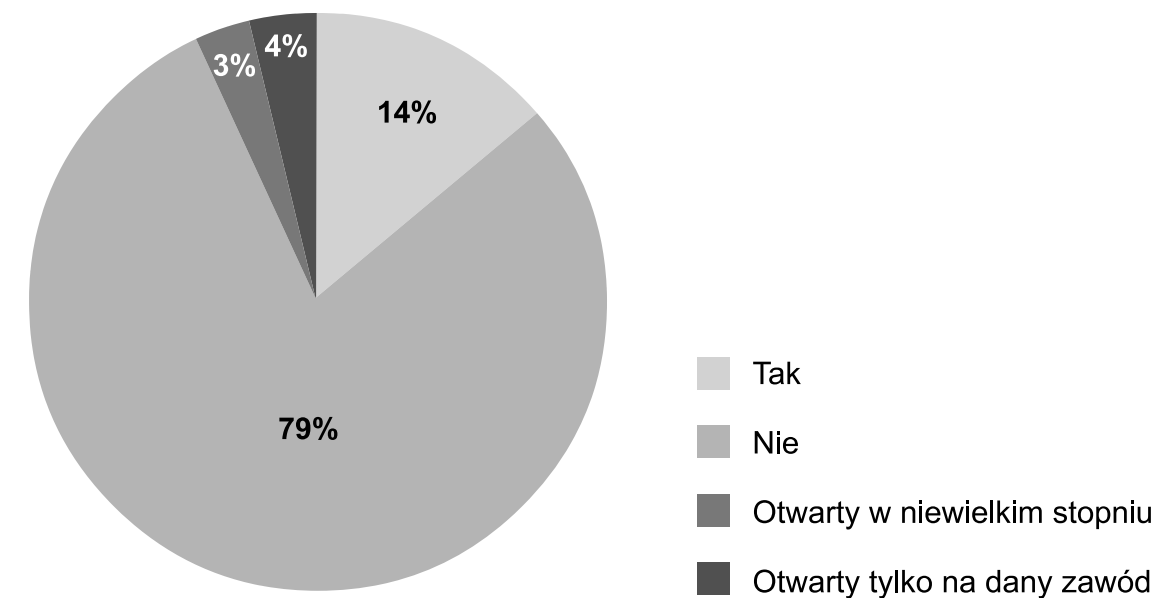

Rysunek 6. Otwartość rynku pracy na kandydatów g/Głuchych według respondentów Źródło: badania własne.

Ocena respondentów dotycząca braku umiejętności komunikowania się w języku migowym wśród specjalistów działu HR nosi znamiona dominanty odbierającej kandydatom z uszkodzeniem słuchu szansę na uczestniczenie w procesie rekrutacji. Aż 89\% ankietowanych uznaje brak znajomości języka wizualno-przestrzennego (PJM) za niekompetencję rekruterów odbierającą osobie g/Głuchej możliwość zaprezentowania swojej kandydatury.

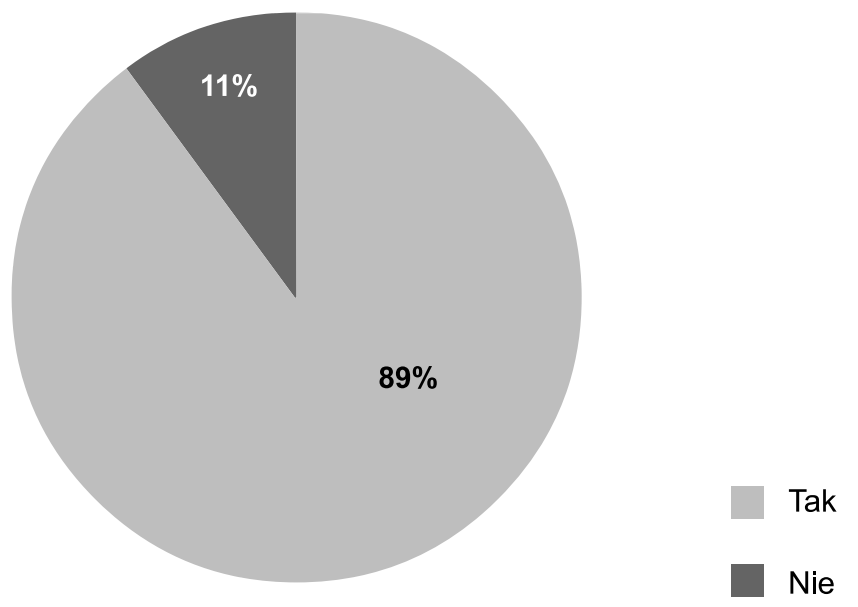

Rysunek 7. Opinia respondentów dotycząca niekorzystnego dla kandydatów z uszkodzeniem słuchu aspektu nieposiadania przez rekrutujących kompetencji w polskim języku migowym 
Zdaniem 40,5\% ankietowanych zainteresowanie kandydatami g/Głuchymi biorącymi udział w procesie rekrutacji jest niewielkie, natomiast 45,6\% ogółu badanych uważa, że takie zainteresowanie w ogóle nie występuje. Z kolei 10,5\% respondentów określa zainteresowanie ich kandydaturami w procesie rekrutacji jako przeciętne, $1,7 \%$ badanych jako wysokie i także $1,7 \%$ - jako bardzo wysokie.

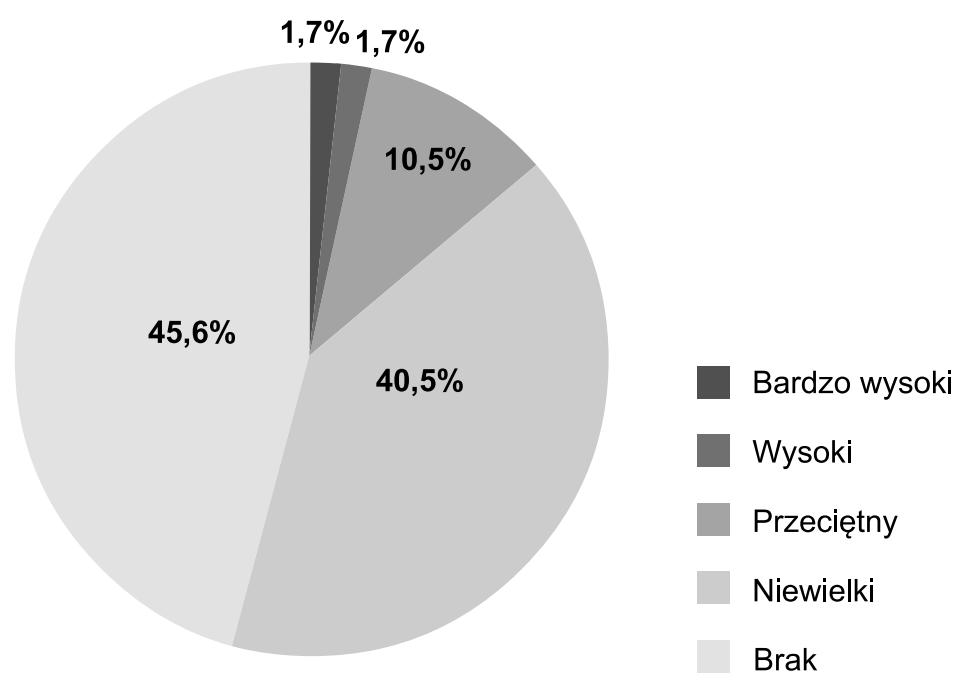

Rysunek 8. Poziom zainteresowania rekruterów kandydatami g/Głuchymi w procesie rekrutacji według respondentów

Źródło: badania własne.

Za przyczynę takiej sytuacji 89,5\% g/Głuchych biorących udział w badaniu uważa postrzeganie osób z uszkodzeniem słuchu jako niepełnowartościowych kandydatów do pracy, chociaż $11 \%$ ogółu badanych nie podziela tej opinii. Jest to ważny problem badawczy, który ujawniło pytanie sondujące, mające przybliżyć dane o postrzeganiu kandydatów g/Głuchych w procesie rekrutacji. Ponadto spośród pięciu wskazanych w pytaniu trudności pojawiających się w trakcie poszukiwania pracy najistotniejszą - bo wskazaną przez wszystkich ankietowanych - okazał się brak wsparcia w procesie rekrutacji (100\%). Jako kolejne ankietowani wymienili bariery komunikacyjne $(78,9 \%)$ oraz niechęć lub brak chęci do rekrutowania kandydatów niepełnosprawnych $(73,6 \%)$. Na dalszych miejscach znalazły się problemy dotyczące uzyskania odpowiednich kwalifikacji $(21,1 \%)$ oraz niewielkie doświadczenie zawodowe $(26,4 \%)$. W pytaniu o to, jakie trudności pojawiają się w poszukiwaniu pracy, ankietowani mogli zaznaczyć więcej niż jedną odpowiedź. 


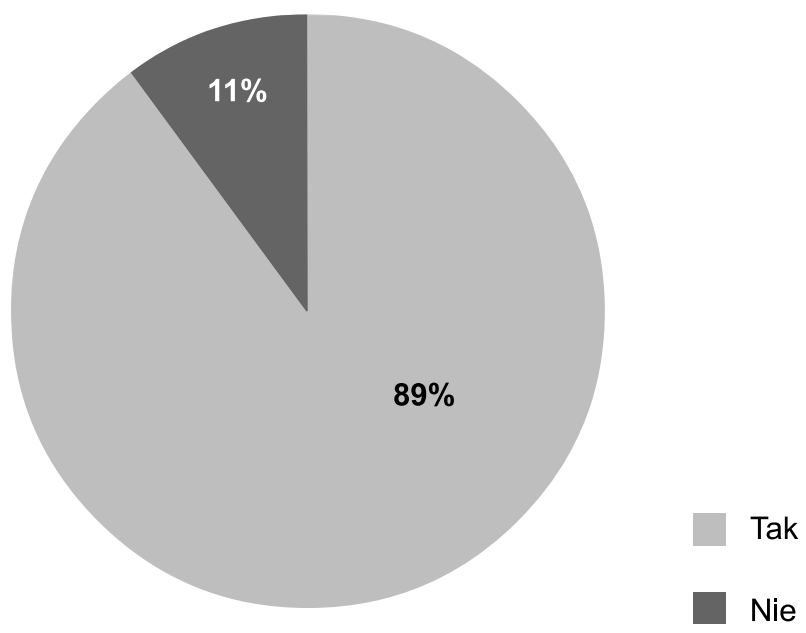

Rysunek 9. Opinia ankietowanych dotycząca postrzegania głuchych kandydatów przez rekruterów

Źródło: opracowanie własne.

Respondenci biorący udział w badaniu kwestionariuszem ankiety to osoby w wieku produkcyjnym. Najwięcej, tj. 85\%, to g/Głusi między 26. a 34. rokiem życia. Ponad 10\% ankietowanych stanowiło najmłodszą grupę, a 5\% najstarszą. Ze wszystkich badanych aż 94,8\% uważa, że otwartość specjalistów HR na g/Głuchych w procesie rekrutacji, danie szansy na zaprezentowanie swoich umiejętności i predyspozycji przez kandydatów z uszkodzeniem słuchu byłoby konkretnym wsparciem oraz czynnikiem motywującym do aktywności zawodowej. Przekonanie, że nie miałoby to większego znaczenia, podziela tylko 5,2\% g/Głuchych.

Badania zostały przeprowadzone za pomocą ankiety wśród organizacji trudniących się prowadzaniem procesów rekrutacyjnych i za pomocą kwestionariusza ankiety wśród osób g/Głuchych. Umożliwiły one pozyskanie istotnych danych dotyczących problematyki przedstawionej w oparciu o literaturę i źródła internetowe. Wyniki uzyskane dzięki powyższym narzędziom badawczym potwierdzają konieczność zdobywania praktycznych doświadczeń mających związek z procesem zatrudnienia osób g/Głuchych w organizacjach dla ich wspólnej współpracy i sukcesu. Zarządzanie zasobami ludzkimi powinno być wolne od błędnych założeń, uprzedzeń i stereotypów. Tylko działy HR posiadające dostateczną ilość wiedzy na temat współpracy z kandydatami o zróżnicowanej sprawności są gotowe na wdrożenie koncepcji zarządzania różnorodnością, która w niedługim czasie jest w stanie przynieść każdej ze stron zadowalające rezultaty. 


\section{Rekomendacje dla organizacji ze szczególnym uwzględnieniem Głuchych w procesie rekrutacji}

Zarządzanie różnorodnością to ,strategia zarządzania personelem, opierająca się na przekonaniu, że jego różnorodność jest jednym z kluczowych zasobów organizacji, który w określonych warunkach może stać się źródłem korzyści biznesowych" (Mrówczyński, 2012: 384). Innymi słowy, to dostrzeganie potencjału w niejednolitości jednostek i konkretne działania w celu rozwoju projektów, strategii i programów, dzięki którym poszanowanie i zagospodarowanie różnic czyni organizację beneficjentem korzyści płynących ze świadomej polityki personalnej. Zgodnie z powyższą koncepcją różnice uwidaczniające się wśród osób wyrażających zaangażowanie w obszarze aktywności zawodowej należy postrzegać jako możliwość odniesienia sukcesu przez przedsiębiorstwo. Konsekwentne wykorzystywanie praktyk zwiększających zróżnicowanie w określonych wymiarach kapitału ludzkiego gwarantuje organizacji pełną realizację postawionych przez nią celów (Olsen, Martins, 2012: 1168). Zgodnie z artykułem 13 Dyrektywy Rady 2000/78/WE w sprawie ustanowienia ogólnych ram równego traktowania przy zatrudnieniu i wykonywaniu zawodu bez względu na religię lub wyznanie, niepełnosprawność, wiek i orientację seksualną w państwach członkowskich Unii Europejskiej powstały własne akty prawa antydyskryminacyjnego. Dały one początek kompleksowemu procesowi działań społecznych, których wynikiem miało być poprawienie sprawności psychofizycznej i przywrócenie do aktywnego życia zawodowego. Organizacje, które decydują się wdrożyć koncepcję zarządzania zróżnicowanym potencjałem ludzkim pod względem sprawności słuchowej, mogą liczyć na wsparcie instytucji rządowych i pozarządowych, zajmujących się tworzeniem i realizowaniem wyżej wspomnianego procesu na wielu płaszczyznach.

Tabela 3. Przykłady instytucji wspierających organizacje przy zatrudnieniu Głuchych

\begin{tabular}{|c|c|}
\hline Instytucja & Zadania \\
\hline Polski Związek Głuchych & $\begin{array}{l}\text { W swoich zadaniach ma zapewniać tłumaczy } \\
\text { dostępnych dla wszystkich Głuchych bez względu na } \\
\text { członkostwo w PZG. }\end{array}$ \\
\hline Miejskie Ośrodki Pomocy Społecznej & $\begin{array}{l}\text { Instytucje mające możliwość dofinansowania usługi } \\
\text { tłumacza języka migowego. }\end{array}$ \\
\hline $\begin{array}{l}\text { Państwowy Fundusz Rehabilitacji Osób } \\
\text { Niepełnosprawnych }\end{array}$ & $\begin{array}{l}\text { Zajmuje się między innymi dofinansowaniem } \\
\text { stanowisk dla pracodawców chcących zatrudniać lub } \\
\text { zatrudniających osoby niepełnosprawne. }\end{array}$ \\
\hline Urząd Pracy & $\begin{array}{l}\text { Zapewnia wsparcie doradcy zawodowego, gwarantuje } \\
\text { pomoc w przygotowaniu głuchego kandydata do pracy, } \\
\text { zbadanie jego kompetencji, skierowanie na szkolenia } \\
\text { lub kursy zawodowe w celu rozwinięcia kompetencji. } \\
\text { Świadczy pomoc w znalezieniu i skierowaniu głuchego } \\
\text { kandydata do zainteresowanego pracodawcy. }\end{array}$ \\
\hline
\end{tabular}


Tabela 3 cd.

\begin{tabular}{|l|l|}
\hline \multicolumn{1}{|c|}{ Instytucja } & \multicolumn{1}{c|}{ Zadania } \\
\hline $\begin{array}{l}\text { Fundacje zajmujące się aktywizacją } \\
\text { osób wykluczonych społecznie }\end{array}$ & $\begin{array}{l}\text { Prowadzą warsztaty zawodowe i kursy dające } \\
\text { uprawnienia do wykonywania zawodów. }\end{array}$ \\
\hline $\begin{array}{l}\text { Fundacje i stowarzyszenia prowadzące } \\
\text { projekty wsparcia zawodowego }\end{array}$ & $\begin{array}{l}\text { Prowadzą rekrutację uczestników, projekty, utrzymują } \\
\text { kontakt z pracodawcami, promują inicjatywy } \\
\text { w środowisku niepełnosprawnych oraz pracodawców. }\end{array}$ \\
\hline $\begin{array}{l}\text { Biuro Pełnomocnika Rządu ds. Osób } \\
\text { Niepełnosprawnych }\end{array}$ & $\begin{array}{l}\text { Prowadzi działania na rzecz osób } \\
\text { z niepełnosprawnościami. }\end{array}$ \\
\hline $\begin{array}{l}\text { Podmioty stworzone z myślą } \\
\text { o Głuchych i słabosłyszących }\end{array}$ & $\begin{array}{l}\text { Członkami są tłumacze online, agencje rekrutacji } \\
\text { osób głuchych. Zapewniają tłumaczenie i wsparcie } \\
\text { w zatrudnieniu. }\end{array}$ \\
\hline $\begin{array}{l}\text { Ochotnicze Hufce Pracy i agencje } \\
\text { zatrudnienia }\end{array}$ & $\begin{array}{l}\text { Zajmują się rekrutacją i wsparciem w zatrudnieniu osób } \\
\text { niepełnosprawnych. }\end{array}$ \\
\hline Sejmik Osób Niepełnosprawnych & $\begin{array}{l}\text { Członkami są trenerzy pracy, specjaliści od } \\
\text { prawa i finansów związanych z zatrudnianiem } \\
\text { niepełnosprawnych osób. Misją jest poprawa jakości } \\
\text { życia osób niepełnosprawnych. }\end{array}$ \\
\hline
\end{tabular}

Źródło: Snapshot dla jednostek publicznych (w tym Jednostek Samorządu Terytorialnego), 2014.

Rozwój współpracy i partnerstwo z instytucjami publicznymi, współuczestniczenie w badaniach i projektach ośrodków akademickich, zmiana praktyk w obszarze miejsc pracy to czynności ukierunkowane na tworzenie świadomej polityki personalnej przedsiębiorstwa. W podejmowanych przez organizację decyzjach dotyczących rozpoczęcia poszukiwań pracownika także wśród niepełnosprawnych słuchowo wyróżnić można cztery kroki:

1. Potrzebę zatrudnienia pracownika - z uwzględnieniem osoby Głuchej.

2. Proces rekrutacji.

3. Przygotowanie lub/i dostosowanie miejsca pracy do współpracy z Głuchym pracownikiem.

4. Wdrożenie Głuchego kandydata do pracy i wsparcie na dalszych etapach zatrudnienia. (Bugajska i in., 2019).

Proces rekrutacyjny w organizacji, która uwzględni osoby z uszkodzeniem słuchu, nie będzie odbiegał dalece od sposobu pozyskiwania innych kandydatów do pracy. Umieszczenie ogłoszenia o pracę także na portalach rekrutacyjnych zajmujących się aktywizacją osób głuchych, współpraca z instytucjami w celu pomocy w rozpowszechnieniu informacji o prowadzonej rekrutacji czy zawarcie informacji o otwartości rekrutacji dla osób niepełnosprawnych słuchowo zachęci osoby głuche do aplikowania na tak przedstawioną ofertę pracy. Według poradnika dla pracodawców decydujących się na zatrudnienie osób z niepełnosprawnością słuchową dobrą praktyką jest zamieszczenie ogłoszenia w postaci nagrania w języku migowym (Bugajska i in., 2019). W dalszym etapie, jakim jest rozmowa kwalifikacyjna, ważne jest, aby osoby prowadzące rekrutację zarezerwowały większą ilość czasu na spotkanie. Osoby Głuche nie posługują się biegle językiem polskim, jest on dla nich językiem obcym. W związku z tym należy brać pod 
uwagę występowanie ewentualnie błędów językowych w przygotowanym przez niesłyszącego kandydata liście motywacyjnym i CV. Nie powinny one jednak dyskredytować osoby z uszkodzeniem słuchu jako godnego uwagi kandydata w procesie rekrutacji. Kolejny etap, jakim jest projektowanie środowiska pracy dla głuchych pracowników, powinien uwzględniać wszystko, co związane jest z organizacją. Odpowiednie przygotowanie pozwala uniknąć dezinformacji, a racjonalne dostosowanie warunków, bezpieczeństwa i tworzenie życzliwej atmosfery będzie sprzyjać osiąganiu sukcesów.

Tabela 4. Wytyczne w kwestii dostosowania miejsca pracy do wymagań wynikających z niepełnosprawności słuchowej

\begin{tabular}{|c|c|c|c|}
\hline $\begin{array}{c}\text { Możliwości } \\
\text { zatrudnienia }\end{array}$ & $\begin{array}{l}\text { Wymagania } \\
\text { techniczne }\end{array}$ & $\begin{array}{l}\text { Wymagania } \\
\text { środowiskowe }\end{array}$ & Organizacja pracy \\
\hline $\begin{array}{l}\text { każde stanowisko pod } \\
\text { warunkiem odpowied- } \\
\text { niego dostosowania }\end{array}$ & $\begin{array}{l}\text { - aparat słuchowy we- } \\
\text { dle zaleceń lekarza } \\
\text { - nauszniki ochronne } \\
\text { w przypadku pracy } \\
\text { w hałasie (nawet } \\
\text { gdy normy nie są } \\
\text { przekroczone) } \\
\text { - komunikatory i sy- } \\
\text { gnalizatory świetlne } \\
\text { zastępujące komuni- } \\
\text { kację dźwiękową } \\
\text { - urządzenia elek- } \\
\text { troakustyczne } \\
\text { w przypadku pracy } \\
\text { w pomieszczeniach } \\
\text { użytku zbiorowego } \\
\text { - dodatkowe zabez- } \\
\text { pieczenia na wypa- } \\
\text { dek utraty równowa- } \\
\text { gi w przypadku pracy } \\
\text { na wysokościach }\end{array}$ & $\begin{array}{l}\text { - w przypadku osób, } \\
\text { u których występuje } \\
\text { głuchota jedno- } \\
\text { stronna, stanowi- } \\
\text { sko powinno być } \\
\text { ulokowane tak, aby } \\
\text { sprawne ucho było } \\
\text { skierowane w stronę } \\
\text { pozostałych współ- } \\
\text { pracowników lub } \\
\text { klientów } \\
\text { - stanowisko pracy } \\
\text { musi być tak dosto- } \\
\text { sowane, aby zabez- } \\
\text { pieczało przed utratą } \\
\text { bądź pogorszeniem } \\
\text { posiadanej zdolności } \\
\text { słyszenia } \\
\text { - dla osób niesłyszą- } \\
\text { cych instrukcje ob- } \\
\text { sługi oraz instrukcje } \\
\text { bhp powinny być } \\
\text { udostępnione w po- } \\
\text { staci obrazkowej } \\
\text { lub w postaci filmu } \\
\text { z lektorem polskiego } \\
\text { języka migowego }\end{array}$ & $\begin{array}{l}\text { - pracownik musi mieć } \\
\text { możliwość utrzyma- } \\
\text { nia komunikacji innej } \\
\text { niż głosowa (komu- } \\
\text { nikator, sygnalizator } \\
\text { świetlny) } \\
\text { - pracownik musi } \\
\text { mieć zapewnioną } \\
\text { możliwość wezwania } \\
\text { osoby, która będzie } \\
\text { wspierać pracownika } \\
\text { w procesie komuni- } \\
\text { kacyjnym } \\
\text { - jeśli praca wykony- } \\
\text { wana jest w miej- } \\
\text { scach niebezpiecz- } \\
\text { nych dla życia lub } \\
\text { zdrowia, muszą być } \\
\text { zapewnione bardzo } \\
\text { czytelne sygnały } \\
\text { świetlne } \\
\text { - jeśli praca wyko- } \\
\text { nywana jest na } \\
\text { wysokościach, nie- } \\
\text { pełnosprawnemu po- } \\
\text { winien towarzyszyć } \\
\text { asystent ze względu } \\
\text { na możliwość utraty } \\
\text { równowagi } \\
\text { - współpracownicy } \\
\text { powinni być prze- } \\
\text { szkoleni w zakresie } \\
\text { komunikacji } \\
\text { - opis czynności } \\
\text { i regulamin powinny } \\
\text { widnieć w formie } \\
\text { graficznej i pisemnej }\end{array}$ \\
\hline
\end{tabular}

Źródło: Lodołamacze. Konkurs dla pracodawców wrażliwych społecznie. 
Należy mieć na uwadze, że zatrudnienie osoby z uszkodzeniem słuchu to połączenie świata ciszy ze światem słyszących, dlatego obecność tłumacza języka migowego jest gwarancją płynnej i swobodnej komunikacji. Wskazane jest korzystanie z takiego wsparcia podczas rozmów kwalifikacyjnych, jak również w pierwszych dniach pracy wdrażanego do zakresu obowiązków głuchego pracownika. W tym miejscu należy podkreślić istotę art. 30 Konwencji o prawach osób niepełnosprawnych $^{2}$, której pkt 4 mówi, że osoby niepełnosprawne słuchowo mają prawo na równi z innymi obywatelami do uznania swojej tożsamości kulturowej i językowej, a więc języków migowych (polski język migowy).

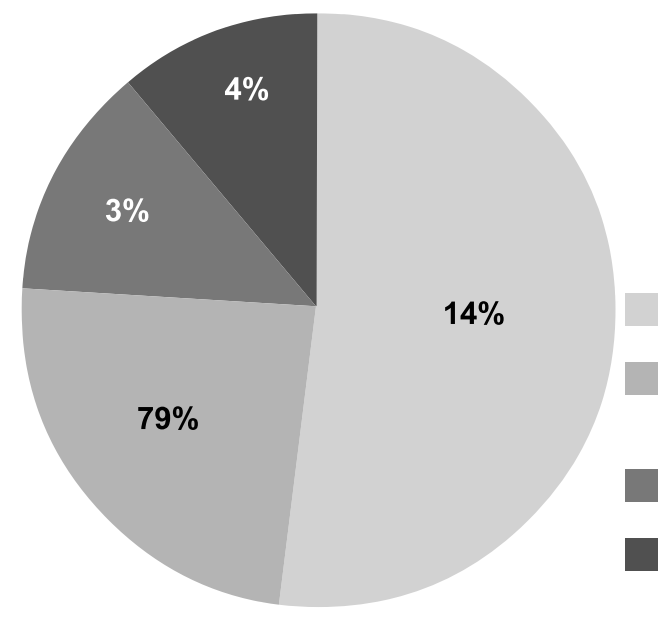

Tłumacz języka migowego

Rekruter ze znajomością polskiego języka migowego

Korzystanie z pomocy tłumacza on-line

Możliwość przyjścia z osobą słyszącą posługującą się językiem migowym

Rysunek 10. Proponowane rozwiązania dla wsparcia komunikacji z osobą głuchą w procesie rekrutacji

Źródło: opracowanie własne.

Potrzebę asysty tłumacza języka migowego wskazują sami zainteresowani. W przeprowadzonym z udziałem osób głuchych i słabosłyszących badaniu własnym większość ankietowanych w jednej z trzech możliwych odpowiedzi wskazała tłumacza języka migowego jako najlepszego rodzaju wsparcie w procesie rekrutacyjnym dla kandydatów słabosłyszących i głuchych (52\%). Kolejnym rozwiązaniem zarekomendowanym przez $24 \%$ ankietowanych była opcja rekrutera ze znajomością polskiego języka migowego. Spośród badanych 13\% wybrałoby możliwość przyjścia na rozmowę rekrutacyjną z osobą słyszącą posługującą się PJM (polski język migowy), natomiast korzystanie z pomocy tłumacza online respondenci wskazali jako czwarte

${ }^{2}$ Konwencja o prawach osób niepełnosprawnych została przyjęta w dniu 13 grudnia 2006 roku przez Zgromadzenie Ogólne Narodów Zjednoczonych w Nowym Jorku. Weszła w życie 3 maja 2008 roku na mocy rezolucji nr 61/106. W dniu 30 marca 2007 roku Polska podpisała Konwencję, a ratyfikowała ją 6 września 2012 roku. Od 25 października 2012 roku Konwencja wiążę Polskę w stosunkach wewnętrznych i zewnętrznych, po opublikowaniu jej w Dzienniku Urzędowym z 2012 roku, poz. 1169. 
rozwiązanie (11\%) (Dudziak, 2020: 54). Organizacje, które zdecydują się ponadto na zatrudnienie wspomagane (ang. Assisted Employment), zyskują trenera pracy. Przy kooperacji z działem HR zapewnia on sprawne przeprowadzenie procesu rekrutacji, dopasowanie kandydata do stanowiska pracy oraz wsparcie w miejscu pracy osoby głuchej. Służy on też profesjonalnym doradztwem całemu środowisku w przedsiębiorstwie. „Trener pracy jest zaangażowany także w rozwiązywanie problemów osoby g/Głuchej, a zatem nie skupia się jedynie na samym zatrudnieniu, ale wspomaga w eliminowaniu różnych przeszkód stojących na drodze do osiągnięcia sukcesu zawodowego" (Osoby gtuche w Polsce 2020. Wyzwania i rekomendacje. Raport Komisji Ekspertów ds. Osób Głuchych, 2020). Usługa zatrudnienia wspomaganego ${ }^{3}$ ma charakter ciągły zarówno dla zatrudnionego, jak i zatrudniającego. W przypadku zmian zakresu czynności, potrzeby uzyskania pomocy organizacyjnej bądź prawnej, a także trudności w wykonywaniu zadań dostęp do wykwalifikowanego trenera pracy jest stały (Domańska, 2016: 94).

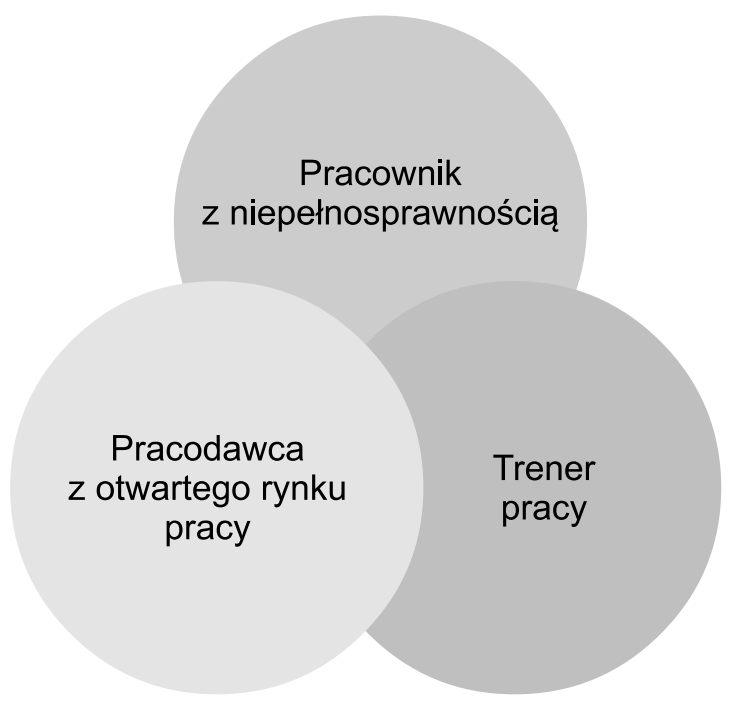

Rysunek 11. Współdziałanie podmiotów w zatrudnieniu wspomaganym

Źródło: Oferta dla pracodawców.

Możliwości zawodowe osób głuchych chcących pozostawać aktywnymi są niemalże nieograniczone. Osoba $\mathrm{z}$ niepełnosprawnością słuchową po odpowiednim przygotowaniu, dostosowaniu przez organizację stanowiska pracy oraz wsparciu zespołu będzie mogła wykonywać wszystkie przewidziane dla niej zawodowe

${ }^{3}$ Zatrudnienie wspomagane - bezpłatna usługa skierowana do pracodawców z otwartego rynku pracy, gotowych zatrudnić osobę niepełnosprawną słuchowo. Taka usługa dostępna jest w Polskiej Federacji Zatrudnienia Wspomaganego oraz Polskiej Fundacji Pomocy Dzieciom Niedosłyszącym ECHO. 
czynności. Ważne jest, aby próba włączenia osób głuchych do funkcjonowania w przedsiębiorstwie nie zawężała się do skupienia na samych ograniczeniach wynikających z niepełnosprawności słuchowej. Kierowanie się przez organizację zasadą równych szans w procesie rekrutacji, wytyczanie ścieżki kariery głuchym pracownikom, zagwarantowanie im dostępu do szkoleń, zachęcanie do uczestniczenia w procedurach awansu, jak również do czynnego udziału w wydarzeniach organizowanych w miejscu pracy jest właściwym i świadomym zarządzaniem różnorodnością, które umożliwia organizacji osiągnięcie ogromnych korzyści, dając jej przewagę konkurencyjną. Żeby do tego doszło, organizacja powinna otworzyć się na zmaksymalizowanie zatrudnienia ponadprzeciętnych jednostek z różnorodnych środowisk. Oznacza to zmianę w podejściu do niepełnosprawności słuchowej i postrzeganie osoby z uszkodzeniem słuchu przede wszystkim jako osoby. Konieczne wydaje się wymaganie od działu odpowiedzialnego w organizacji za zatrudnienie otwartości na inność i uwolnienie od stereotypów na temat niepełnosprawności słuchowej. Równie istotna jest determinacja działu kadr we wdrażaniu koncepcji zarządzania różnorodnością, począwszy od tworzenia procesu rekrutacji uwzględniającego niesłyszących, po prezentowanie profesjonalnej postawy podczas tego procesu, jak również przez całą ścieżkę kariery osoby głuchej w przedsiębiorstwie. Jedyne, czego potrzeba, to zrozumienie i wyjście naprzeciw we wzajemnej komunikacji, dzięki czemu w procesie rekrutacji nie ma miejsca na wykluczenie zawodowe.

\section{Podsumowanie}

Wykluczenie zawodowe Głuchych jest zjawiskiem złożonym i wielowymiarowym. W znaczący sposób związane jest z zewnętrznymi czynnikami, których efektem są różne przejawy dyskryminacji bezpośredniej. Z punktu widzenia osób z niepełnosprawnością słuchową dostęp do rynku pracy jest im ograniczany poprzez wykluczanie ich z procesu rekrutacji. Ograniczenie dostępu do zatrudnienia skutkuje szeregiem negatywnych konsekwencji społeczno-ekonomicznych. Badania pokazują, że zbiorowość Głuchych dotknięta wykluczeniem zawodowym jest liczna pomimo sprzyjającego komunikacji rozwoju technologicznego, korzystnych zmian legislacyjnych oraz coraz intensywniej adaptującej się w przedsiębiorstwach koncepcji zarządzania różnorodnością. Jak słusznie zauważają badacze, kluczową rolę odgrywają postawy pracodawców, lekarzy medycyny pracy, ale przede wszystkim specjalistów działu HR w organizacji poszukującej pracownika. Kształtowanie struktury zatrudnienia nie może opierać się na wykluczaniu z procesu rekrutacji osób g/Głuchych z powodu ich odmiennej komunikacji. Nieustanne doskonalenie, prowadzenie badań i analiz rozwoju koncepcji zarządzania różnorodnością są drogą do właściwej i świadomej polityki zatrudnienia. Działalność organizacji na rzecz równych szans w procesie rekrutacji jest niezbędna, by budować nowe wartości w relacjach międzyludzkich oraz pracowniczych. W innym przypadku wykluczenie zawodowe tej 
mniejszościowej grupy społecznej, jaką są osoby z uszkodzeniem słuchu, będzie nie tylko faktem, ale także łamaniem fundamentalnych praw człowieka, które gwarantuje nie tylko Konstytucja Rzeczypospolitej Polskiej.

\section{Bibliografia}

„, Gtuchy pracownik”. Poradnik dla pracodawców, http://dobrekadry.pl/wp-content/ uploads/2019/01/KARTA-4 Poradnik-dla-pracodawco $\%$ CC $\% 81 w . p d f$ [dostęp: 20.03.2021].

Biuletyn Informacji Publicznej RPO, Rzecznik Praw Obywatelskich, https://bip.brpo. gov.pl/ [dostęp: 6.01.2022].

Bugajska J., Kapica Ł., Kamińska J., Młyń R., Radosz J., Pawlak A., Skupień A., Hadław A., Żmuda Ł., Sokołowski M., Pora H., Spychała E., Łuczywek S. (2019), Osoba z niepetnosprawnościa stuchowa w pracy. Poradnik dla pracodawców, https://www.ciop.pl/CIOPPortalWAR/file/88314/Osoba_z niepelnosprawnoscia sluchowa_w pracy-Poradnik_dla pracodawcow.pdf [dostęp: 21.03.2020].

Czajkowska-Kisil M., Niepetnosprawność słuchowa jako przesłanka dyskryminacji, V seminarium specjalistyczne pt. „Niepełnosprawność wzrokowa, wzorkowo-słuchowa i niepełnosprawność słuchowa jako przesłanki dyskryminacji w ramach Specjalistycznej Szkoły Facylitacji Społecznej na rzecz Przeciwdziałania Dyskryminacji, https://docplayer.pl/27548-Niepelnosprawnosc -sluchowa-jako-przeslanka-dyskryminacji.html [dostęp: 6.01.2022].

Domańska L. (2016), Zatrudnienie wspomagane szansą dla osób niepetnosprawnych, „Opuscula Sociologica”, nr 2.

Dudziak K. (2020), Koncepcja zarządzania różnorodnościa. Osoby Głuche i słabostyszace w procesie rekrutacji, Praca dyplomowa, Uniwersytet Jagielloński, Kraków.

Dunaj M. (2014), Osoby głuche na rynku pracy, [w:] M. Świdziński (red.), Sytuacja osób głuchych w Polsce. Raport zespołu ds. g/Gtuchych przy Rzeczniku Praw Obywatelskich, Biuro Rzecznika Praw Obywatelskich, Warszawa.

Faliszek K. (2008), Partycypacja i wykluczenie wspołeczności lokalnej, [w:] K. Wódz, S. Pawlas-Czyż (red.), Praca socjalna wobec nowych obszarów wykluczenia społecznego: modele teoretyczne, potrzeby praktyki, Wydawnictwo Edukacyjne „Akapit”, Toruń.

Golinowska S. (red.) (2004), W trosce o pracę. Raport o Rozwoju Społecznym Polska 2004, http://www.unic.un.org.pl/nhdr/nhdr2004/nhdr2004 pl.pdf [dostęp: 1.12.2021].

Gross-Gołacka E. (2018), Przesłanki do wprowadzania koncepcji zarządzania różnorodnościa w polskich organizacjach, „Journal of Modern Science”, No. 36(1). 
Keil M., Amershi B., Holmes S., Jablonski H., Lüthi E., Matoba K., Plett A., von Unruh K. (2007), Poradnik szkoleniowy. Zarządzanie różnorodnościa, https:// www.idm-diversity.org/files/EU0708-TrainingManual-pl.pdf [dostęp: 1.12.2021].

Klincewicz K. (2016), Zarzadzanie, organizacje i organizowanie. Przegląd perspektyw teoretycznych, Wydawnictwo Naukowe Wydziału Zarządzania Uniwersytetu Warszawskiego, Warszawa.

Konwencja o prawach osób niepełnosprawnych (2018), Ministerstwo Rodziny i Polityki Społecznej, https://www.gov.pl/web/rodzina/konwencja-o-prawach-osob-niepelnosprawnych [dostęp: 21.03.2021].

Kryńska E. (2013), Analiza sytuacji osób niepetnosprawnych w Polsce $i$ Unii Europejskiej. Raport przygotowany w ramach projektu „Zatrudnienie osób niepetnosprawnych - perspektywy wzrostu”, IPiSS, Warszawa.

Kubicki P. (2011), Ubóstwo i wykluczenie spoleczne osób starszych, https://www. researchgate.net/publication/236829087_Ubostwo_i_wykluczenie_spoleczne osob starszych [dostęp: 17.03.2021].

Kukla D. (2004), Poradnictwo zawodowe i praca zawodowa jako integralny proces rewalidacji zawodowej osób niepetnosprawnych, „Edukacja Ustawiczna Dorosłych", $\mathrm{nr} 4$.

Lipczyński A. (2015), Marginalizacja w Polsce: jej przyczyny i skutki, https://www. pulib.sk [dostęp: 14.03.2021].

Lodołamacze. Konkurs dla pracodawców wrażliwych społecznie, Polska Organizacja Pracodawców Osób Niepełnosprawnych, http://www.lodolamacze.info. pl [dostęp: 21.03.2021].

Mrówczyński P. (2012), Zarządzanie różnorodnościa wynikiem zmian w zarządzaniu zasobami ludzkimi, „Prace Naukowe Uniwersytetu Ekonomicznego we Wrocławiu", nr 248.

National activity Report Slovakia anti-discrimination and diversity training (2008), International Society for Diversity Management, https:/www.yumpu.com/ en/document/read/22497235/pdf-en-idm-international-society-for-diversity -management [dostęp: 6.01.2022].

Niewiadomska A. (2018), Wykluczenie zawodowe osób starszych w Polsce - próba oceny, „Facta Ficta Journal of Narrative, Theory \& Media”, No. 1(1).

Oferta dla pracodawców, Polska Federacja Zatrudnienia Wspomaganego, http:// pfzw.pl/oferta-dla-pracodawcow/ [dostęp: 24.03.2021].

Olsen J.E., Martins L.L. (2012), Understanding organizational diversity management programs: A theoretical framework and directions for future research, „Journal of Organizational Behavior”, Vol. 33(8).

Osoby gluche w Polsce 2020. Wyzwania i rekomendacje. Raport Komisji Ekspertów ds. Osób Gtuchych (2020), https://www.rpo.gov.pl/sites/default/files/ Osoby Gluche w Polsce 2020 Wyzwania i Rekomendacje.pdf [dostęp: 25.03.2021]. 
Osoby niepetnosprawne na rynku pracy w 2011 r. (2012), Główny Urząd Statystyczny, https://stat.gov.pl/cps/rde/xbcr/gus/pw osoby niepelnosprawne na rynku_pracy_w 2011.pdf [dostęp: 20.03.2021].

Piotrowska D. (2015), Zespoły zróżnicowane pod kąem sprawności, „Personel i Zarządzanie", z. 4.

Rudnicka E. (2011), Czy Gtuchy jest głupi-studium powiąań wyrazów, które uległy rozpodobnieniu semantycznemu, „LingVaria”, $\mathrm{nr}$ 2(12).

Skorny Z. (1989), Mechanizmy regulacyjne ludzkiego działania, PWN, Warszawa.

Snapshot dla jednostek publicznych (w tym Jednostek Samorzadu Terytorialnego) (2014), http://www.kulturagluchych.pl/photos cms/PDF/snapshot 3.pdf [dostęp: 21.03.2021].

Szkoła tolerancji, Centrum Edukacji Obywatelskiej, https://szkolatolerancji.ceo.org. pl/ [dostęp: 28.03.2021].

Świdziński M. (red.) (2014), Sytuacja osób głuchych w Polsce. Raport zespołu ds. g/Gtuchych przy Rzeczniku Praw Obywatelskich, https://www.rpo.gov.pl/ sites/default/files/Raport_Sytuacja_osob_poz\%203 srodki 2\%20XII.pdf [dostęp: 14.03.2021].

Tabin M. (red.) (2005), Słownik socjologii i nauk społecznych, Wydawnictwo Naukowe PWN, Warszawa.

Teper-Solarz Z. (2013), Projekt innowacyjny MIGACZ: szansa na aktywizację zawodowa i integrację społeczna niestyszacych?, „Pisma Humanistyczne”, z. 11.

Teper-Solarz Z. (2016), Wzrost mobilności a integracja społeczna i aktywizacja zawodowa osób niestyszacych - za kulisami innowacyjnego projektu testujacego PI - MIGACZ wspierajacego głuchych w uzyskaniu prawa jazdy, [w:] U. Bartnikowska, A. Żyta, S. Przybyliński (red.), Inkluzja-marginalizacja wykluczenie jakość życia osób z niepetnosprawnością. Wyzwania współczesności, Wydawnictwo Uniwersytetu Warmińsko-Mazurskiego, Olsztyn.

\section{Akty prawne}

Konwencja o prawach osób niepełnosprawnych, sporządzona w Nowym Jorku dnia 13 grudnia 2006 r., Dz.U. 2012, poz. 1169.

Ustawa z dnia 19 sierpnia 2011 r. o języku migowym i innych środkach komunikowania się, Dz.U. 2011, nr 209, poz. 1243. 


\section{Summary}

The phenomenon of professional exclusion of deaf people in the recruitment process in Poland

Occupational exclusion affects the D/deaf of all ages, regardless of their financial status, level of education or place of residence. Despite technological progress and development in the area of human capital management, the scale of the occupational exclusion of people with hearing impairment in Poland makes it impossible for them to fully participate in social life. This raises some disturbing questions: "Where should we look for the reasons for this type of marginalization?' 'Is a convention needed in order to respect the essential human right to professional activity?' If so, does the responsibility for implementing such regulations and recommendations rest with the state or private organisations? Over the years, ideas about d/Deaf people and hearing impairment have built up strong prejudices in the world where hearing and speaking is one of the most basic forms of communication. Even though the interested parties themselves come out to manifest their need for professional activity, they still remain on the margins of the recruitment process.

Keywords: the Deaf, exclusion, recruitment process, stereotypes, diversity management 